University of Nebraska - Lincoln

DigitalCommons@University of Nebraska - Lincoln

Publications, Agencies and Staff of the U.S.

Department of Commerce

U.S. Department of Commerce

1991

\title{
Long-Term Decline in Freshwater Mussels (Bivalvia: Unionidae) of the Western Basin of Lake Erie
}

\author{
Thomas F. Nalepa \\ Great Lakes Environmental Research Laboratory, thomas.nalepa@noaa.gov \\ Bruce A. Manny \\ National Fisheries Research Center-Great Lakes \\ James C. Roth \\ University of California - Berkeley \\ Samuel C. Mozley \\ North Carolina State University at Raleigh \\ Donald W. Schloesser \\ National Fisheries Research Center-Great Lakes
}

Follow this and additional works at: https://digitalcommons.unl.edu/usdeptcommercepub

Part of the Environmental Sciences Commons

\footnotetext{
Nalepa, Thomas F.; Manny, Bruce A.; Roth, James C.; Mozley, Samuel C.; and Schloesser, Donald W., "Long-Term Decline in Freshwater Mussels (Bivalvia: Unionidae) of the Western Basin of Lake Erie" (1991). Publications, Agencies and Staff of the U.S. Department of Commerce. 389.

https://digitalcommons.unl.edu/usdeptcommercepub/389

This Article is brought to you for free and open access by the U.S. Department of Commerce at DigitalCommons@University of Nebraska - Lincoln. It has been accepted for inclusion in Publications, Agencies and Staff of the U.S. Department of Commerce by an authorized administrator of DigitalCommons@University of Nebraska - Lincoln.
} 


\title{
LONG-TERM DECLINE IN FRESHWATER MUSSELS (BIVALVIA: UNIONIDAE) OF THE WESTERN BASIN OF LAKE ERIE
}

\author{
Thomas F. Nalepa ${ }^{1}$, Bruce A. Manny ${ }^{2}$, James C. Roth ${ }^{3}$, \\ Samuel C. Mozley ${ }^{4}$, and Donald W. Schloesser ${ }^{2}$
}

\begin{abstract}
Long-term trends in the abundance of unionids in the western basin of Lake Erie were examined from data collected at 17 stations in 1961, 1972, and 1982. The mean number of unionids at these stations declined over this time period, decreasing from $10 \mathrm{~m}^{-2}$ in 1961 , to $6 \mathrm{~m}^{-2}$ in 1972, down to $4 \mathrm{~m}^{-2}$ in 1982. This decline in abundance was reflected in the decrease in the number of stations where mussels were found; unionids were found at 16 of the 17 stations in 1961, but at only 6 stations in 1982. Reasons for the decrease in the unionid population are not generally apparent, but are probably related to the decline in water quality and periods of low oxygen levels over the time period of the surveys.

INDEX WORDS: Mussels, mollusks, benthic fauna, Lake Erie, pollution effects.
\end{abstract}

\section{INTRODUCTION}

Through the years, the macroinvertebrate community of the western basin of Lake Erie has undergone some dramatic changes. The decline of Hexagenia populations in the 1950 s and the subsequent increase in the number of oligochaetes, chironomids, and sphaeriids in the 1960 s clearly demonstrated the negative impact of pollutant loadings into the basin (Britt 1955, Carr and Hiltunen 1965 ). Since the early 1970 s, water quality conditions have generally improved as a result of phosphorus control measures (El-Shaarawi 1987), and, at least in certain areas of the basin, Hexagenia is becoming re-established (Thornley 1985) and oligochaete numbers have declined (D. W. Schloesser et al. unpublished manuscript).

Historically, the western basin of Lake Erie has been characterized as having one of the richest and most abundant unionid assemblages in North America (Goodrich and van der Schalie 1932). The basin's relatively shallow depth and high flushing rate ("river-lake habitat") provide conditions that are highly favorable to unionid populations. In

\footnotetext{
Great Lakes Environmental Research Laboratory, 2205 Commonwealth Blvd., Ann Arbor, Michigan 48105

2National Fisheries Research Center-Great Lakes, 1451 Green Rd., Ann Arbor, Michigan 48105

3Sanitary Engineering and Environmental Health Laboratory, University of California-Berkeley, 1301 S. 46th St., Richmond, California 94804

${ }^{4}$ Department of Zoology, North Carolina State University, Raleigh, North Carolina 27695
}

addition, former stream connections in the postglacial period allowed a diverse assemblage of species from the Ohio-Mississippi basin to populate the area (van der Schalie 1941). Of the 39 species recorded in the Great Lakes, 36 are known to have inhabited Lake Erie, and most of these were once found in the western basin (Mackie et al. 1980).

While unionid populations in the western basin have apparently declined over the past few decades (Wood and Fink 1984), quantitative evidence of these declines are lacking. When Carr and Hiltunen (1965) documented changes of most benthic groups in the period between 1930 and 1961 , quantitative changes in unionid populations were not included because the 1930 data set (Wright 1955) did not include abundance estimates for unionids. Wood and Fink (1984) compared unionid populations in 1973-74 to populations found in 1951-52; however, they used a dragdredge which did not allow abundances to be reported with certainty.

This paper documents changes in the abundance and species composition of mussel populations in the western basin of Lake Erie over the 21-year period between 1961 and 1982. The data were obtained from surveys conducted in 1961 (Carr and Hiltunen 1965), 1972 (J. C. Roth and S. C. Mozley unpublished data), and 1982 (B. A. Manny et al. unpublished manuscript). 


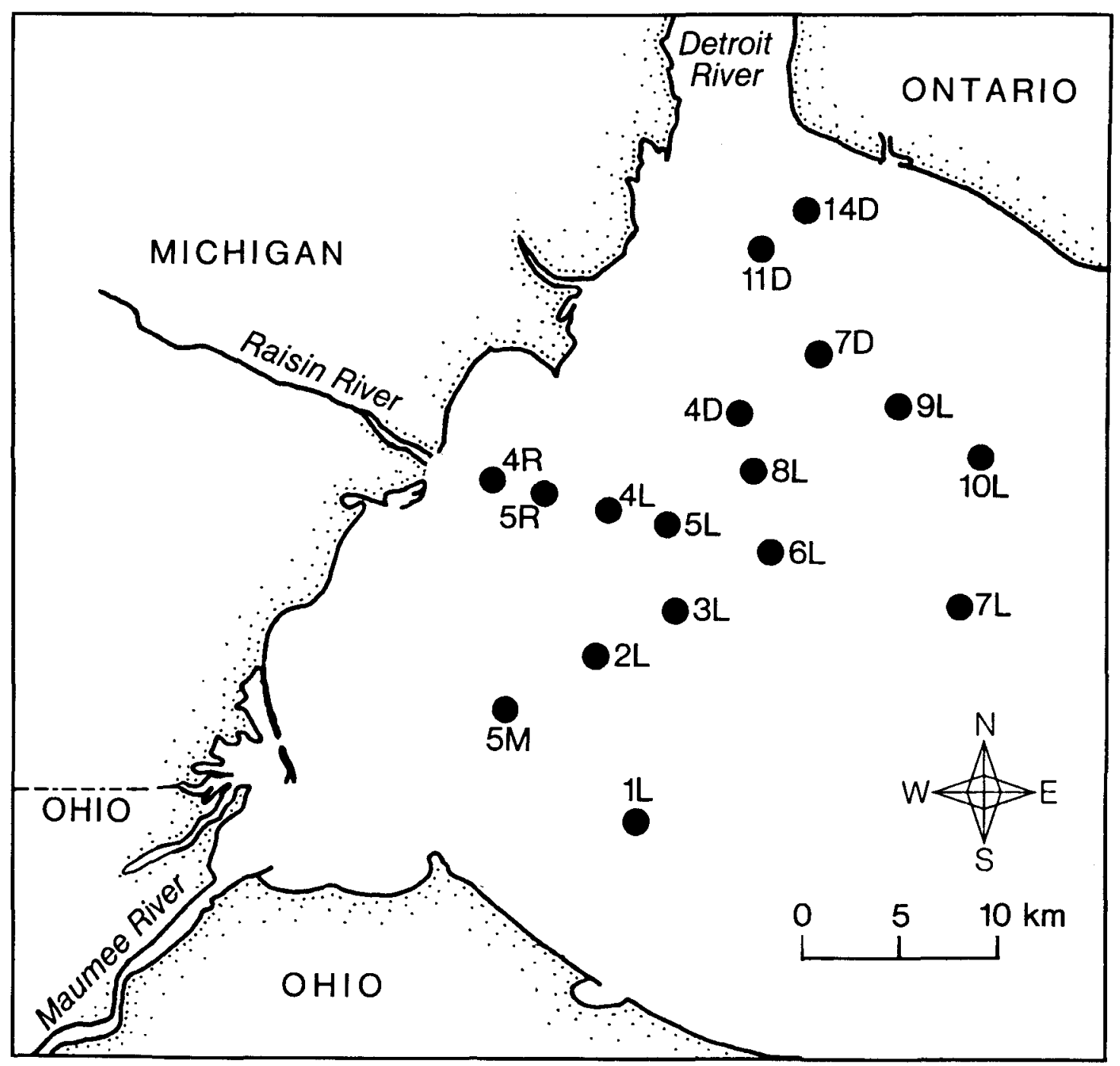

FIG. 1. Location of sampling stations in western Lake Erie.

\section{METHODS}

Locations of the 17 stations sampled in each of the three surveys are given in Figure 1. Most of the stations were located in the open, offshore waters of the basin. An additional 23 stations, located over a broader area of the basin, were sampled in 1961 and 1982 only. Exact locations (longitude and latitude) of all stations are given in Carr and Hiltunen (1965). Sampling methods and procedures were basically similar in the three surveys (Table 1). Carr and Hiltunen (1965) used a Peterson grab, while both Roth and Mozley (unpublished data) and Manny et al. (unpublished manu- script) used a Ponar grab. Although the Peterson grab is less efficient than the Ponar in collecting most benthic invertebrate forms (Flannagan 1970), efficiencies of the two grabs are likely to be similar when collecting unionids. The greater "shockwave" of the Peterson, which blows away small organisms at the sediment surface just before impact, should not have any effect on these large, heavy-shelled forms. The effect is minimal even for the shelled but much smaller Sphaeriidae (Flannagan 1970, Nalepa et al. 1988). While grab samplers generally underestimate unionid abundances (Haukioja and Hakala 1974, Isom and Gooch 1986, Nalepa and Gauvin 1988), any bias in abun- 
TABLE 1. Summary of sampling methods of the three surveys that have given density estimates of Unionidae in the western basin of Lake Erie.

\begin{tabular}{lccc}
\hline \hline & \multicolumn{3}{c}{ Survey } \\
\cline { 2 - 4 } & $\begin{array}{c}\text { Carr and Hiltunen } \\
(1965)\end{array}$ & $\begin{array}{c}\text { Roth and Mozley } \\
\text { (unpublished) }\end{array}$ & $\begin{array}{c}\text { Manny et al. } \\
\text { (unpublished) }\end{array}$ \\
\hline Year sampled & 1961 & 1972 & 1982 \\
Replicates/Station & 3 & 5 & 3 \\
Grab sampler & Peterson & Ponar & Ponar \\
Sieve size & $0.6 \mathrm{~mm}$ & $1.3 \mathrm{~mm}$ & $0.6 \mathrm{~mm}$ \\
\hline
\end{tabular}

dance estimates should be reflected similarly in the three surveys. The coarser mesh screen used by Roth and Mozley to sieve sediments was fine enough to retain all mussels older than 1 year.

The 1961 survey data, as published by Carr and Hiltunen (1965), contained some errors in the reported abundance and species composition of unionids Jarl K. Hiltunen, personal communication, 1990); the 1961 data given in this paper contain the necessary corrections.

\section{RESULTS AND DISCUSSION}

A general decline in the abundance and distribution of unionids in the western basin of Lake Erie between 1961 and 1982 was apparent (Table 2). Mean abundances at the 17 stations in 1961, 1972, and 1982 were $10 \mathrm{~m}^{-2}, 6 \mathrm{~m}^{-2}$, and $4 \mathrm{~m}^{-2}$, respectively. This decline in mean abundance is reflected in the dramatic decrease in the number of stations at which unionids were collected. In 1961, mussels were found at 16 of the 17 stations, but this number declined to 11 in 1972 and to only 6 by 1982 . The number of species collected also declined over this period, with 7 species found in 1961, 6 in 1972, and 5 in 1982. Two of the species collected in 1982, Lampsilis $r$. siliquoidea and Ligumia nasuta, were the most common species in 1961 and 1972. To provide a broader perspective on the decline of species in the western basin, the species reported from surveys conducted in 1930 (Wright 1955), in 1951-52 (Wood 1963), and in 1973-74 (Wood and Fink 1984) are presented, along with the species reported in the surveys of 1961, 1972, and 1982 (Table 3). The species found in the 1961 and 1982 surveys include those species found at all 40 of the sampled stations. The same 40 stations were originally sampled in 1930 (Wright 1955) so, at least qualitatively, these three surveys may be considered directly comparable. The number of species did not change substantially between 1930 and 1961, with 12 species being found in the former year and 10 in the latter; however, only 5 species were found in 1982 (Table 3). A similar decline was reported by Wood and Fink (1984); a total of 14 species were found in the open lake in 1951-52 but only 4 species were found in 1973-74 (Table 3). Further, they reported that the proportion of recently dead shells (two valves attached and

TABLE 2. Abundances of Unionidae (numbers per square meter) in the western basin of Lake Erie at 17 stations that were sampled in each of the three surveys; 1961 (Carr and Hiltunen), 1972 (Roth and Mozley unpublished), and 1982 (Manny et al. unpublished manuscript).

\begin{tabular}{lrcr}
\hline \hline & \multicolumn{3}{c}{ Year } \\
\cline { 2 - 4 } Station & 1961 & 1972 & 1982 \\
\hline 1L & 13 & 0 & 7 \\
2L & 0 & 0 & 0 \\
3L & 30 & 8 & 0 \\
4L & 8 & 8 & 0 \\
5L & 4 & 12 & 7 \\
6L & 22 & 8 & 0 \\
7L & 8 & 4 & 14 \\
8L & 18 & 20 & 0 \\
9L & 4 & 8 & 0 \\
10L & 4 & 4 & 0 \\
4D & 8 & 0 & 14 \\
7D & 8 & 12 & 0 \\
11D & 4 & 0 & 0 \\
14D & 4 & 8 & 21 \\
4R & 8 & 0 & 0 \\
5R & 14 & 4 & 7 \\
5M & 9 & 0 & 0 \\
Mean & 9.8 & 5.6 & 4.1 \\
SE & 1.9 & 1.4 & 1.6 \\
\% of stations & & & \\
with unionids & 94.1 & 64.7 & 35.3 \\
\hline
\end{tabular}


TABLE 3. A list of unionid species collected and the percent each species comprised of the total number collected in various surveys in the western basin of Lake Erie; 1930 (Wright 1955), 1951-52 (Wood 1963), 1961 (Carr and Hiltunen 1965), 1972 (Roth and Mozley unpublished), 1973-74 (Wood and Fink 1984), and 1982 (Manny et al. unpublished manuscript). Because a dragdredge was used to collect unionids in the surveys of 1952-53 and 1973-74 and the area sampled was much larger than in the other surveys, the number of species collected in these two surveys is not directly comparable to the number collected in the other surveys. Also, only 17 stations were sampled in the 1972 survey while 40 stations were sampled in the 1930, 1961, and 1982 surveys.

\begin{tabular}{|c|c|c|}
\hline $1930^{*}$ & $1951-52$ & 1961 \\
\hline Lampsilis $r$. siliquoidea & Lampsilis $r$. siliquoidea $(62.4)$ & Lampsilis $r$. siliquoidea $(30.8)$ \\
\hline Liqumia nasuta & Liqumia nasuta $(7.8)$ & Liqumia nasuta (25.6) \\
\hline Anodonta grandis & Leptodea fraqilis (6.9) & Anodonta grandis (20.5) \\
\hline Lampsilis ventricosa & Lampsilis ventricosa (4.2) & Lampsilis ventricosa (5.1) \\
\hline Elliptio dilatatus & Elliptio dilatatus (4.2) & Leptodea laevissima (5.1) \\
\hline Fusconia flava & Anodonta grandis (3.3) & Elliptio dilitata (2.6) \\
\hline Leptodea fragilis & Fusconia flava (3.0) & Obliquaria reflexa (2.6) \\
\hline Proptera alata & Proptera alata (3.0) & Leptodea fraqilis (2.6) \\
\hline Truncilla donaciformis & Truncilla donaciformis (2.4) & Proptera alata (2.6) \\
\hline Truncilla truncilla & Amblema costata $(1.5)$ & Truncilla donaciformis (2.6) \\
\hline Obovaria leibii & Obliquaria reflexa $(0.6)$ & \\
\hline Strophitus rugosus & Quadrula pustulosa (0.3) & \\
\hline & Pleurobema cordatum $(0.3)$ & \\
\hline & Obovaria subrotunda (0.3) & \\
\hline 1972 & $1973-74 * *$ & 1982 \\
\hline Lampsilis $r$. siliquoidea $(62.5)$ & Lampsilis $r$. siliquoidea $(76.4)$ & Lampsilis $r$. siliquoidea $(46.2)$ \\
\hline Liqumia nasuta (8.3) & Leptodea fraqilis (16.8) & Liqumia nasuta (23.1) \\
\hline Anodonta grandis (8.3) & Liqumia nasuta (3.40) & Amblema plicata (15.4) \\
\hline Leptodea laevissina (8.3) & Proptera alata (3.4) & Proptera alata (7.6) \\
\hline Lampsilis ventricosa $(8.3)$ & & Anodonta grandis (7.6) \\
\hline Proptera alata (4.2) & & \\
\hline
\end{tabular}

*Relative abundances of the various species were not given.

**Percentages were extrapolated from pie graphs.

intact) in the samples increased from $29 \%$ in $1951-52$ to $79 \%$ in $1973-74$.

Specific reasons for the decrease in unionid populations of the western basin are not immediately apparent, but are likely related to the general decline in water quality over the time period of these surveys (Burns 1985). Studies have shown that mussels are sensitive to low oxygen concentrations, with at least $6 \mathrm{ppm}$ required for normal growth and between 2.5 and $5 \mathrm{ppm}$ needed for continued survival (Fuller 1974). Between 1961 and 1982, oxygen concentrations in the western basin fell below these critical levels during periods of calm weather; concentrations of less than $3 \mathrm{ppm}$ were recorded in the summers of 1963 (Carr et al. 1965.), 1966 (Britt e al. 1968), 1971 (Hartman 1972), and 1973 (Zapotsky and Herdendorf 1980). Shifts in the composition of the fish community can also have an impact on mussel populations, but populations of fish species that may serve as potential hosts for mussel glochidia, i.e., yellow perch, white bass, freshwater drum, channel catfish, etc. (Fuller 1974), have remained stable or increased in the western basin over the past few decades (Hartman 1972, Leach and Nepszy 1976).

Besides western Lake Erie, other areas which once had developed unionid populations, such as Green Bay and Saginaw Bay, now have an impoverished fauna (Mackie et al. 1980). However, an abundant and diverse mussel population still exists in Lake St. Clair (Nalepa and Gauvin 1988); this is probably because this lake is continuously flushed with high quality water from Lake Huron and oxygen concentrations remain close to saturation (Herdendorf et al. 1986). Although conditions in the western basin have generally improved since the 1960 s, as evidenced by a recovering Hexagenia population (Thornley 1985), it may take several 
decades before these improvements are reflected, if at all, in a recovery of the unionid population. Many of the species that are no longer found in the offshore waters of the basin are still present in shallow, nearshore areas where wave action keeps the waters well-oxygenated (J. C. Roth and S. C. Mozley unpublished, Wood and Fink 1984). Over time, these areas may be a source of individuals to repopulate offshore areas. However, a new threat to the unionid population is the recent introduction and rapid increase of the zebra mussel, Dreissena polymorpha. Samples from the western basin in the fall of 1989 showed that all unionids were covered with Dreissena at densities of up to 10,000 per individual (D. W. Schloesser and T. F. Nalepa, unpublished data). Given these densities, the longterm impacts of Dreissena on an already stressed unionid population needs to be closely monitored.

\section{ACKNOWLEDGMENTS}

We thank John H. Judd (deceased) for assistance in the 1982 survey and Jarl K. Hiltunen for interpretation and corrections of the 1961 survey data. The 1972 survey was conducted while the authors JCR and SCM were at the Great Lakes Research Division, University of Michigan. The support of that institution is appreciated. Contribution No. 717 of the Great Lakes Environmental Research Laboratory and No. 766 of the National Fisheries Research Center-Great Lakes.

\section{REFERENCES}

Britt, N. W. 1955. Stratification in western Lake Erie in summer 1953: effects on the Hexagenia (Ephemeroptera) population. Ecology 36:239-244.

Skoch, E. J., and Smith, K. R. 1968.

Record low dissolved oxygen in the island area of Lake Erie. Ohio J. Sci. 68:157-179.

Burns, N. M. 1985. Erie The Lake That Survived. Totowa, N.J.: Rowan and Allanheld.

Carr, J. F., and Hiltunen, J. K. 1965. Changes in the bottom fauna of western Lake Erie from 1930 to 1961. Limnol. Oceanogr. 10:551-569.

Applegate, V. C., and Keller, M. 1965. A recent occurrence of thermal stratification and low dissolved oxygen in western Lake Erie. Ohio J. Sci. 65:319-327.

El-Shaarawi, A. H. 1987. Water quality changes in Lake Erie, 1968-1980. J. Great Lakes Res. 13: 674-683.

Flannagan, J. F. 1970. Efficiencies of various grabs and corers in sampling freshwater benthos. J. Fish. Res. Board Can. 27:1691-1700.
Fuller, S. L. H. 1974. Clams and mussels (Mollusca and Bivalvia). In Pollution Ecology of Freshwater Invertebrates, eds. C. W. Hart, Jr. and S. L. H. Fuller, pp. 215-273. New York: Academic Press.

Goodrich, C., and van der Schalie, H. 1932. The naiad species of the Great Lakes. Occ. Papers Mus. Zool. University Michigan 238:8-14.

Hartman, W. L. 1972. Lake Erie: effects of exploitation, environmental changes, and new species on the fisheries resources. J. Fish. Res. Board Can. 29: 899-912.

Haukioja, E., and Hakala, T. 1974. Vertical distribution of freshwater mussels (Pelycepoda, Unionidae) in southwestern Finland. Ann. Zool. Fennici. 11: 127-130.

Herdendorf, C. E., Raphael, C. N., and Jaworski, E. 1986. The ecology of Lake St. Clair wetlands: a community profile. U.S. Fish. Wildl. Ser. Viol. Rep. 85(7.7), Washington, D.C.

Isom, B. G., and Gooch, C. 1986. Rationale and sampling designs for freshwater mussels Unionidae in streams, large rivers, impoundments, and lakes. In Rationale for sampling and interpretation of ecological data in the assessment of freshwater systems, ed. B. G. Isom, pp. 46-59. Philadelphia, PA: ASTM STP, American Society for Testing and Materials.

Leach, J. H., and Nepszy, S. J. 1976. The fish community in Lake Erie. J. Fish. Res. Board Can. 33: 622-638.

Mackie, G. L., White, D. S., and Zdeba, T. W. 1980. $A$ guide to freshwater mollusks of the Laurentian Great Lakes with special emphasis of the genus Pisidium. U.S. Environmental Protection Agency EPA-600/380-068. Office of Research and Development, Duluth, Minnesota.

Nalepa, T. F., and Gauvin, J. M. 1988. Distribution, abundance, and biomass of freshwater mussels (Bivalvia: Unionidae) in Lake St. Clair. J. Great Lakes Res. 14:411-419.

Quigley, M. A., and Ziegler, R. W. 1988. Sampling efficiency of the Ponar grab in two different benthic environments. J. Great Lakes Res. 14: 89-93.

Thornley, S. 1985. Macrozoobenthos of the Detroit and St. Clair rivers with comparisons to neighboring waters. J. Great Lakes Res. 11:404-418.

van der Schalie, H. 1941. The taxonomy of naiades inhabiting a lake environment. $J$. Conchol. 21: 246-253.

Wood, K. G. 1963. The bottom fauna of western Lake Erie. In Univ. Michigan Great Lakes Res. Div. Publ. No. 10, pp. 258-265. Ann Arbor, Michigan.

, and Fink, T. J. 1984. Ecological succession of macrobenthos in deep- and shallow-water environments of western Lake Erie: 1930-1974. In Proc. 4th Internat. Conf. Ephemeroptera, eds. V. Landa et al., pp. 263-279. CSAV. 
Wright, S. 1955. Limnological survey of western Lake Erie. U.S. Fish Wildl. Ser. Spec. Sci. Rept. Fisheries No. 139, Washington, D.C.

Zaptosky, J. E., and Herdendorf, C. F. 1980. Oxygen depletion and anoxia in the central and western basins of Lake Erie, 1973-1975. In Lake Erie Nutrient Control Program, ed. C. F. Herdendorf, pp. 71-102. EPA-600/3-8-062. 